\title{
The Effect of Sample Geometry and Placement of Sample on Microwave Processing of Iron Ore
}

\author{
K. Barani, S. M. J. Koleini, B. Rezai, and A. Khodadadi
}

\begin{abstract}
Sample and oven factors are important in determining the magnitude and uniformity of power absorption. In this research, the effect of sample and oven parameters such as sample volume and placement of sample on microwave heating of water and an iron ore material were studied and obtained data were compared. The results showed that for water heating, with increasing in sample volume from 200 to $1000 \mathrm{~cm}^{3}$ the microwave energy absorbed by water was increased from 71.27 to $100 \%$, also with increasing in sample surface area from 50.24 to $78.50 \mathrm{~cm}^{2}$ the microwave, energy absorbed by water was increased from 76.36 to $89.09 \%$. With increasing iron ore sample volume without increasing in surface area, the microwave absorption was constant whereas with increasing in sample surface area from 50.24 to $126.6 \mathrm{~cm}^{2}$, the microwave energy absorbed by iron ore was increased from 36.6 to $61.82 \%$. The maximum temperature for iron ore material was occurred at $5.7 \mathrm{~cm}$ distance from the center whereas the maximum temperature for water sample was occurred at $5 \mathrm{~cm}$ distance from the center.
\end{abstract}

Index Terms-Iron ore, microwave treatment, mineral processing, sample geometry.

\section{INTRODUCTION}

Microwaves are electromagnetic waves with frequencies from $300 \mathrm{MHz}$ to $300 \mathrm{GHz}$ and wavelengths from one to $300 \mathrm{~mm}$. $2450 \mathrm{MHz}$ is the most commonly utilized frequency for the home microwave oven. Microwave heating is unique and has many advantages over conventional heating such as rapid heating, material selective heating and volumetric heating. In recent years, many potential applications of microwave processing in minerals treatment have been investigated. These included microwave assisted ore grinding, microwave assisted carbothermic reduction of metal oxides, microwave-assisted drying and anhydration, microwave-assisted minerals leaching, microwave-assisted roasting and smelting of sulfide concentrates, microwave-assisted pretreatment of refractory gold concentrates, microwave-assisted spent carbon regeneration and microwave-assisted waste management [1]. Compared with conventional heating, heat transfer in microwave heating is typically more difficult to study due to the complex interaction of the microwave with the cavity and the sample. The magnitude and uniformity are affected by both sample and oven factors [2]-[4].

Manuscript received February 9, 2012; revise March 25, 2012.

K. Barani is with Mining Dept., Lorestan University, Khorramabad, (email:Irankianosh1356@yahoo.com).

S. M. J. Koleini and A. Khodadadi are with Mineral Processing Dept., Tarbiat Modares University, Tehran (email:Irankoleini@modares.ac.ir; adarban@modares.ac.ir).

B. Rezai is with Mining Engineering Dept., Amir Kabir University, Tehran, Iran (email:crezai1@yahoo.com).
Sample factors, such as volume, surface area, and dielectric properties and oven factors, such as placement inside the oven, oven size and geometry, turntable, Mode stirrers and feed location, are important in determining the magnitude and uniformity of power absorption. Power absorption can vary significantly with aspect ratio, defined as surface area/volume $\left(\mathrm{cm}^{2} / \mathrm{cm}^{3}\right)$. Previous researches showed The significant increase in power absorption with aspect ratio is mainly due to surface heating of ham that has a small penetration depth and this trend may not be true for low loss material [5]-[7]. The magnitude of energy absorption in materials is obviously related to the power output of the magnetron. For a given magnetron, the energy absorption is primarily a function of the impedance of the oven system. The overall impedance includes the geometry and placement of the material, size and geometry of the cavity and waveguide, and location and geometry of the feed ports [8], [9]. The results of previous researches showed that heating pattern is significantly different for the three locations. Measurements of power distribution using water assume the maximum power absorption of water cells occur at the highest electromagnetic fields inside the cavity [10], [11].

However, interaction of microwave with minerals is poorly understood. Thus, a fundamental understanding of how microwave energy interacts with minerals is the key to unlocking the technology for use in mineral processing industries. To shed more light on the subject of the interaction of microwave with minerals, this research was conducted and the effect of sample factors, such as volume, surface area, size and shape, aspect ratio on the magnitude and uniformity of power absorption by an iron ore sample were studied.

\section{EXPERIMENTAL}

The material used in this research was iron ore that $100 \%$ passed 300 micrometer screen. XRD and chemical analysis were carried out on the material and the results are showed in Table I. The materials were treated in a $2.45 \mathrm{GHz}$ microwave oven (Panasonic, model NN-ST656W, rated power $1100 \mathrm{~W}$, and cavity dimension $333 \times 356 \times 210$ ). The total output power of the oven was calculated according to International standard IEC 705. The result showed that total output power of the oven is $550 \mathrm{~W}$. Medium material (distilled water) was radiated in a $1000 \mathrm{~cm}^{3}$ Pyrex glass cylinder container and target materials (iron ore) were radiated in a Pyrex glass cylinder container that its volume was selected

Based on test conditions. The materials temperature was measured by quickly inserting a K-type thermocouple into the sample after the power was turned off (in order to 
eliminate any interference from the microwaves) and monitored by a digital display temperature controller [12].

TABLE I: XRD AND CHEMICAL ANALYSIS OF IRON ORE MATERIAL

\begin{tabular}{|c|c|c|c|}
\hline \multicolumn{2}{|c|}{ XRD analysis } & \multicolumn{2}{c|}{ Chemical analysis } \\
\hline Mineral & Percent & Compound & Percent \\
\hline Magnetite & 64 & $\mathrm{Fe}$ & 68.02 \\
\hline Hematite & 35 & $\mathrm{FeO}$ & 14.72 \\
\hline Quartz & 1 & $\mathrm{P}$ & 0.09 \\
\hline & & $\mathrm{S}$ & 0.03 \\
\hline
\end{tabular}

In this research, a new practical method was used to determine the microwave energy absorption. According to this method, when the water medium and target material are placed in the cavity and receive microwave irradiation simultaneously, the total output microwave energy is absorbed by both, and transferred into heat energy. If $\mathrm{Q}_{\mathrm{W}}$ is as the microwave energy absorbed by water medium, $\mathrm{Q}_{\mathrm{TM}}$ as the target material, $\mathrm{W}_{\mathrm{TO}}$ as the total output microwave energy into the cavity and $\mathrm{Q}_{\mathrm{LOSS}}$ for all microwave energy losses such as absorbed by containers, cavity wall etc, and the following equations are existed.

$$
\mathbf{W}_{\mathrm{To}}=\mathbf{Q}_{\mathrm{W}}+\mathbf{Q}_{\mathrm{TM}}+\mathbf{Q}_{\mathrm{LOSS}}
$$

If $\mathrm{Q}_{\mathrm{Loss}}$ is controlled in a very small magnitude, then Eq. 1 can be rewritten:

$$
\begin{aligned}
& \mathbf{W}_{\mathrm{TO}}=\mathbf{Q}_{\mathbf{W}}+\mathbf{Q}_{\mathrm{TM}} \\
& \mathbf{Q}_{\mathrm{TM}}=\mathbf{W}_{\mathrm{TO}}-\mathbf{Q}_{\mathbf{W}}
\end{aligned}
$$

The total output microwave energy $\left(\mathrm{W}_{\mathrm{TO}}\right)$ into the cavity is easy to calculate based on the rated power and the work time of microwave oven as follows.

$$
\mathbf{W}_{\mathrm{To}}=\mathbf{k} \mathbf{W}_{\mathrm{EI}}=\mathbf{k P t}
$$

Where $\mathrm{W}_{\text {TO }}$ is total output microwave energy, $\mathrm{W}_{\mathrm{EI}}$ is the total input electricity energy, the energy transfer efficiency of the microwave oven; $\mathrm{P}$ is the rated power of the microwave oven, $\mathrm{W} ; \mathrm{t}$ is the heating time.

The energy absorbed by the water medium, in the case of neglecting its undeterminable heat loss for water vaporization, heat conduction to its container and heat irradiation to its surrounding environment, which is possible and acceptable by selecting optimum operation conditions, can be easily deduced as follows:

$$
Q_{W}=\operatorname{mc}\left(T_{2}-T_{1}\right)
$$

where $\mathrm{Q}_{\mathrm{W}}$ is the energy absorbed by the water medium, $\mathrm{J} ; \mathrm{m}$ is its mass, $\mathrm{kg}$; $\mathrm{c}$ is the specific heat of water, $\mathrm{J} \mathrm{kg}^{-1}{ }^{\circ} \mathrm{C}-1, \mathrm{~T}_{2}$ and $\mathrm{T}_{1}$ are the temperatures after and before heating, ${ }^{\circ} \mathrm{C}$.

\section{RESULT AND DISCUSSION}

\section{A. The Effect of Sample Volume}

The effect of sample volume on the microwave absorption of water was studied. For this purpose, different volume of water in a $1000 \mathrm{~cm}^{3}$ Pyrex glass cylinder container was heated in the oven at $1100 \mathrm{~W}$ rated power. The total output microwave energy $\left(\mathrm{W}_{\mathrm{TO}}\right)$ and the energy absorbed by the water medium $\left(\mathrm{Q}_{\mathrm{W}}\right)$ was calculated. The results are presented in Table II and Fig. 1.

These data show that the microwave energy absorbed by water, increased with increasing in sample volume. As the sample volume was increased from 200 to $1000 \mathrm{~cm}^{3}$, the microwave energy absorption was increased from 70 to $100 \%$. It can be seen, $1000 \mathrm{~cm}^{3}$ water, absorbed the total output microwave energy. If some iron ore material is radiated simultaneously with the water volume in the oven, some part of the total output microwave energy $\left(\mathrm{W}_{\mathrm{TO}}\right)$ will be consumed for heating of the iron ore material $\left(\mathrm{Q}_{\mathrm{TM}}\right)$. Therefore, the microwave energy absorbed by water and iron ore sample can be calculated.

TABLE II: THE EFFECT OF WATER VOLUME SAMPLE ON MiCROWAVE ENERGY ABSORPTION (1100W RATED POWER, 1000 CM3 WATER

\begin{tabular}{|c|c|c|c|c|c|c|}
\hline $\begin{array}{c}\text { Sam Vol } \\
\left(\mathrm{cm}^{3}\right)\end{array}$ & $\begin{array}{c}\mathrm{T} \\
(\mathrm{S})\end{array}$ & $\begin{array}{c}\mathrm{T}_{1} \\
\left({ }^{\circ} \mathrm{C}\right)\end{array}$ & $\begin{array}{c}\mathrm{T}_{2} \\
\left({ }^{\circ} \mathrm{C}\right)\end{array}$ & $\begin{array}{c}\mathrm{W}_{\text {TO }} \\
(\mathrm{kJ})\end{array}$ & $\begin{array}{c}\mathrm{Q}_{\mathrm{W}} \\
(\mathrm{kJ})\end{array}$ & $\begin{array}{c}\text { Abs } \\
(\%)\end{array}$ \\
\hline 200 & 60 & 27 & 55 & 33 & 23.52 & 71.27 \\
\hline 200 & 60 & 29 & 56 & 33 & 22.68 & 68.73 \\
\hline 300 & 60 & 27 & 48 & 33 & 26.46 & 80.18 \\
\hline 300 & 120 & 29 & 73 & 66 & 55.44 & 84.00 \\
\hline 400 & 60 & 26 & 43 & 33 & 28.56 & 86.55 \\
\hline 400 & 120 & 29 & 63 & 66 & 57.12 & 86.55 \\
\hline 500 & 60 & 26 & 40 & 33 & 29.40 & 89.09 \\
\hline 500 & 60 & 28.5 & 42.5 & 33 & 29.40 & 89.09 \\
\hline 500 & 120 & 29 & 57 & 66 & 58.80 & 89.09 \\
\hline 600 & 60 & 26 & 38 & 33 & 30240 & 91.64 \\
\hline 600 & 120 & 29 & 53 & 66 & 60.48 & 91.64 \\
\hline 800 & 120 & 29 & 48.5 & 66 & 65.52 & 99.27 \\
\hline 800 & 120 & 29 & 48 & 66 & 63.84 & 96.73 \\
\hline 1000 & 120 & 24 & 40 & 66 & 67.20 & 101.82 \\
\hline 1000 & 60 & 33 & 41 & 33 & 33.60 & 101.82 \\
\hline
\end{tabular}

TABLE III shows the results of simultaneously microwave radiation of iron ore materials and $1000 \mathrm{~cm}^{3}$ of water in the oven. Water container was placed in the center of the oven and iron material was placed in a $600 \mathrm{~cm}^{3}$ Pyrex glass container next to the water container. In all tests, the microwave rated power and radiation time was adjusted on $1100 \mathrm{~W}$ and $60 \mathrm{~s}$ respectively. As can be seen in Table III, the microwave energy absorbed by iron ore material was constant with increasing in weight of iron ore sample. When the weight of iron ore sample was increased from 400 to $800 \mathrm{gr}$ the percent of microwave energy absorption by iron ore materials in all cases was $36.36 \%$.

\section{B. The Effect of Aspect Ratio}

The effect of aspect ratio on the microwave absorption of water was studied. For this purpose, equal volumes of water were heated in different containers at $1100 \mathrm{~W}$ rated power and $60 \mathrm{~s}$ radiation times. The results are presented in Table IV and show that in equal volumes, the absorbed power was increased with aspect ratio. The effect of aspect ratio 
parameter on the microwave absorption of iron ore was studied. $1000 \mathrm{~cm}^{3}$ water in a 1 liter container and $800 \mathrm{gr}$ iron ore in different container were heated simultaneously at $1100 \mathrm{~W}$ rated power and $60 \mathrm{~s}$ radiation time. Aspect ratio of iron ore samples and microwave energy absorbed by iron ore samples were measured and presented in TABLE V. It can be seen, the absorbed power was increased with aspect ratio. Comparing data in Table IV and 5 show, that aspect ratio parameter is more effective on microwave absorption by iron ore than water. This phenomenon may be due to surface heating of iron ore that has a small microwave penetration depth.

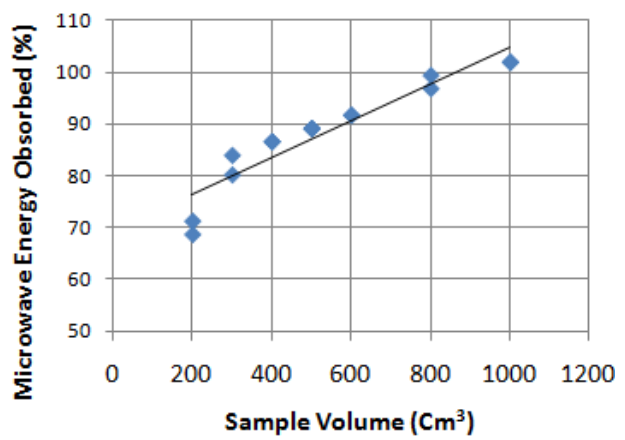

Fig. 1. The effect of water volume sample on microwave energy absorption (1100W rated power, $1000 \mathrm{~cm}^{3}$ container water container).

TABLE III: THE RESULTS OF SIMULTANEOUSLY RADIATION OF WATER AND IRON ORE MATERIAL (1100 W RATED POWER, 1000 CM3 WATER CONTAINER, $600 \mathrm{CM}^{3}$ IRON ORE MATERIAL CONTAINER, $60 \mathrm{~s}$ RADIATION TIME)

\begin{tabular}{|c|c|c|c|c|c|c|}
\hline $\begin{array}{c}\text { Iron } \\
\text { ore } \\
\text { sample } \\
{[\mathrm{gr}]}\end{array}$ & $\begin{array}{c}\mathrm{T}_{1} \text { for } \\
\text { water }\left[{ }^{\circ} \mathrm{C}\right]\end{array}$ & $\begin{array}{c}\mathrm{T}_{2} \text { for } \\
\text { water }\left[{ }^{\circ} \mathrm{C}\right]\end{array}$ & $\begin{array}{c}\mathrm{W}_{\mathrm{TO}} \\
{[\mathrm{kJ}]}\end{array}$ & $\begin{array}{c}\mathrm{Q}_{\mathrm{W}} \\
{[\mathrm{kJ}]}\end{array}$ & Water & $\begin{array}{c}\text { Iron } \\
\text { ore }\end{array}$ \\
\hline 0 & 33 & 41 & 33 & 33.6 & 101.82 & 0 \\
\hline 400 & 33 & 38 & 33 & 21 & 63.64 & 36.36 \\
\hline 400 & 33 & 38 & 33 & 21 & 63.64 & 36.36 \\
\hline 500 & 33 & 38 & 33 & 21 & 63.64 & 36.36 \\
\hline 600 & 33 & 38 & 33 & 21 & 63.64 & 36.36 \\
\hline 700 & 33 & 38 & 33 & 21 & 63.64 & 36.36 \\
\hline 800 & 33 & 38 & 330 & 21 & 63.64 & 36.36 \\
\hline
\end{tabular}

TABLE IV: THE EFFECT OF ASPECT RATIO ON MicrowAVE ABSORPTION BY WATER (1100W RATED POWER, DIFFERENT CONTAINER AND $60 \mathrm{~s}$

\begin{tabular}{|c|c|c|c|c|c|}
\hline \multicolumn{6}{|c|}{ RADIATION TIMES) } \\
\hline $\begin{array}{c}\text { Sample } \\
\text { Vol.[c } \\
\left.\mathrm{m}^{3}\right]\end{array}$ & $\begin{array}{c}\text { Container } \\
{\left[\mathrm{cm}^{3}\right]}\end{array}$ & $\begin{array}{c}\text { surface } \\
\text { area }\left[\mathrm{cm}^{2}\right]\end{array}$ & $\begin{array}{c}\text { Aspect } \\
\text { ratio } \\
{\left[\mathrm{cm}^{2} / \mathrm{cm}^{3}\right]}\end{array}$ & $\begin{array}{l}\mathrm{Q}_{\mathrm{W}} \\
{[\mathrm{kJ}]}\end{array}$ & $\begin{array}{c}\text { Absorption } \\
\text { by } \\
\text { water[\%] }\end{array}$ \\
\hline 300 & 600 & 50.24 & 0.17 & 25.2 & 76.36 \\
\hline 300 & 1000 & 78.50 & 0.26 & 26.46 & 80.18 \\
\hline 400 & 600 & 50.24 & 0.13 & 26.88 & 81.45 \\
\hline 400 & 1000 & 78.50 & 0.20 & 28.56 & 86.55 \\
\hline 500 & 600 & 50.24 & 0.10 & 27.30 & 82.73 \\
\hline 500 & 1000 & 78.50 & 0.16 & 29.40 & 89.09 \\
\hline
\end{tabular}

\section{The Effect of Placement Inside the Oven}

The effect of sample placement inside the oven on microwave energy was studied for water and iron ore. 200 $\mathrm{cm}^{3}$ water with initial temperature 20 centigrade degree in a $250 \mathrm{~cm}^{3}$ container was placed in different position in the oven and heated at 1100 rated power for $60 \mathrm{~s}$. The water temperature was measured quickly after radiation. Data presented in Table VI show that for water sample, with increasing distance from center of the oven, the temperature was increased. As maximum temperature was occurred at 5 $\mathrm{cm}$ distance from the center and then temperature was decreased again.

TABLE V: THE EFFECT OF ASPECT RATIO ON MicRowAVE ABSORPTION BY IRON ORE SAMPLE (1100W RATED POWER, $1000 \mathrm{CM}^{3}$ CONTAINER WATER CONTAINER, 800 GR OR $240 \mathrm{CM}^{3}$ IRON ORE IN DIFFERENT CONTAINER, 60 S RADIATION TIME)

\begin{tabular}{|c|c|c|c|c|}
\hline $\begin{array}{c}\text { Iron ore } \\
\text { container } \\
{[\mathrm{cm} 3]}\end{array}$ & $\begin{array}{c}\text { Surface } \\
\text { area } \\
{\left[\mathrm{cm}^{2}\right]}\end{array}$ & $\begin{array}{c}\text { Aspect } \\
\text { ratio } \\
{\left[\mathrm{cm}^{2} / \mathrm{cm}^{3}\right]}\end{array}$ & $\mathrm{Q}_{\mathrm{TM}}[\mathrm{kJ}]$ & $\begin{array}{c}\text { Absorption by } \\
\text { iron ore[\%] }\end{array}$ \\
\hline 600 & 50.24 & 0.21 & 12 & 36.36 \\
\hline 1000 & 78.50 & 0.33 & 16.2 & 49.09 \\
\hline 1500 & 126.6 & 0.53 & 20.4 & 61.82 \\
\hline
\end{tabular}

TABLE VI: THE EFFECT OF SAMPLE PLACEMENT INSIDE THE OVEN ON MICROWAVE ENERGY ABSORPTION BY WATER (1100 W RATED POWER, $250 \mathrm{CM}^{3}$ WATER CONTAINER, $250 \mathrm{CM}^{3}$ WATER, $60 \mathrm{~S}$ RADIATION TIME)

\begin{tabular}{|c|c|}
\hline Distance from center $[\mathrm{cm}]$ & Temperature $\left[{ }^{\circ} \mathrm{C}\right]$ \\
\hline 0 & 56 \\
\hline 2.5 & 58 \\
\hline 5 & 61 \\
\hline 7.5 & 60 \\
\hline 10 & 57 \\
\hline 12.5 & 56 \\
\hline
\end{tabular}

50 gram iron ore material that $100 \%$ passed throw 100 micrometer screen in a ceramic crucible was placed in different position in the oven and heated at 1100 rated power for $60 \mathrm{~s}$. The material temperature was measured after radiation and showed in Table VII. It can be seen, with increasing distance from center of the oven, the iron ore temperature was increased similar to water. However, the maximum temperature for iron ore material was occurred at $7.5 \mathrm{~cm}$ distance from the center whereas the maximum temperature for water sample was occurred at $5 \mathrm{~cm}$ distance from the center.

TABLE VII: THE EFFECT OF SAMPLE PlACEMENT INSIDE THE OVEN ON MICROWAVE ENERGY ABSORPTION BY IRON ORE MATERIAL (1100W RATED POWER,CRUCIBLE CONTAINER, 50 GR IRON ORE, 60 S RADIATION TIME)

\begin{tabular}{|c|c|}
\hline $\begin{array}{c}\text { Distance from center } \\
{[\mathrm{cm}]}\end{array}$ & $\begin{array}{c}\text { Sample temperature } \\
{\left[{ }^{\circ} \mathrm{C}\right]}\end{array}$ \\
\hline 0 & 205 \\
\hline 0 & 234 \\
\hline 2.5 & 235 \\
\hline 2.5 & 225 \\
\hline 5 & 260 \\
\hline 5 & 261 \\
\hline 7.5 & 355 \\
\hline 7.5 & 344 \\
\hline 7.5 & 340 \\
\hline 10 & 258 \\
\hline 10 & 280 \\
\hline
\end{tabular}

\section{CONCLUSIONS}

Microwave treatment of iron ore is different with 
microwave treatment of water. Iron ore is a low loss material that has a small microwave penetration depth therefore microwave energy absorption is extremely by the surface area of the sample. In equal surface area, with increasing volume, microwave energy absorption by water is increased whereas microwave energy absorption by iron ore is constant. Maximum microwave absorption for water sample and iron ore sample is occurred at different position within an oven. It can be concluded that the nature of radiated materials is effective on energy distribution and intensity of the electromagnetic field within an oven.

\section{ACKNOWLEDGMENT}

Authors would like to thank Lurestan University, Tarbiat Modares University and Iran Central Iron Ore Company for funding this research work.

\section{REFERENCES}

[1] S. W. Kingman, W. Vorster, and N. A. Rawson, "The Influence of Mineralogy on Microwave Assisted Grinding," Minerals Engineering, vol.13, no.3, pp.313-327, 2000

[2] P. O. Risman, T. Ohlsson, and B. Wass, "Principle and models of power density distribution in microwave oven loads," Journal of Microwave Power and Electromagnetic Energy, pp.193-198, 1987.
[3] R. Mudgett, Microwave food processing, Technologist, vol. 22, pp. 4-10, 1989.

[4] C. Saltiel and A. K. Datta, "Heat and mass transfer in microwave processing," Advances in Heat Transfer, vol.32, 1999.

[5] H. Zhang and A. K. Datta, "Microwave power absorption in single and multi-compartment foods," Food and bioproducts, vol. 81, no. 3, pp.257-265, 2003

[6] C. M. Weil, "Absorption characteristics of multilayered sphere exposed to uhf/microwave radiation," IEE Transactions on Biomedical Engineering, vol. 22, pp. 468-476, 1975.

[7] M. Chamchong and A. K. Datta, "Thawing of foods in a microwave oven: Effect of load geometry and dielectric properties," Journal of Microwave Power and Electromagnetic Energy, vol. 34. pp. 22-32. 1999.

[8] X. Jia, "Experimental and numerical study of microwave power distribution in a microwave heating application," Journal of Microwave Power and Electromagnetic Energy, vol. 28, pp. 11-21, 1993.

[9] R. E. Collin, Foundation of Microwave Engineering, McGraw-Hill, New York, 1998.

[10] H. Zhang and A. K. Datta, "Coupled electromagnetic and thermal modeling of microwave oven heating of food," Journal of Microwave Power and Electromagnetic Energy, vol. 5, no. 2, pp.71-85, 2000.

[11] C. S. MacLatchy and R. M. Clements, "A simple technique for measuring high microwave electric field strength," Journal of Microwave Power, vol. 15, pp. 7-14, 1980.

[12] K. Barani, "The Effect of Microwave Treatment upon Dry Grinding Kinetics of Iron Ore," $\mathrm{PhD}$ Thesis, minerals processing, Tarbiat Modares University, Iran, 2011. 